\title{
PATRIMONIALISM AND CORPORATISM AS THE BASIC CONCEPTS IN DEFINING THE SOCIAL STRUCTURE OF TURKEY
}

\author{
Mehmet Devrim TOPSES \\ Doç.Dr., Çanakkale Onsekiz Mart Üniversitesi Fen-Edebiyat Fakültesi Sosyoloji Bölümü, devrimtopses@ @omu.edu.tr, ORCID: https://orcid.org/0000-
} 0003-2753-6369 Topses, Mehmet Devrim. "Patrimonialism and Corporatism as the Basic Concepts in Defining the Social Structure of Turkey".
ulakbilge, 48 (2020 Nisan): s. 520-525. doi: 10.7816/ulakbilge-08-48-03

\begin{abstract}
Patrimonialism and corporatism are the cultural variables that have a determinant importance in explaining the social structure of Turkey. The relations between the individual and the state, likewise those between the individuals, are shaped by the mold of these cultural variables. Patriarchal family ties, hierarchical expectations, weakness of civil society, and the dominant power of the obedience culture are some examples of the effect of these cultural variables on the social structure. Besides, the patrimonialist and corporatist cultural elements have been nourished by the economic and class variables throughout the history in Turkey. Starting from the Gokturk state, the central authority and the despotic state tradition which did not allow the capital accumulation have nurtured the patrimonial culture. On the other hand, the Ottoman state tradition that attaches importance to the concept of "nizam" (order) or the protection of the order even more than the concept of state, has been influential in the development of the codes of the corporatist culture in Turkey. At the beginning of the 20th century, Kemalists took over the political power and supported the view of "corporatist society" as a function of securing their power against the lower classes. Therefore, it is an obvious necessity to use the concepts of corporatism and patrimonialism in explaining the social structure of today's Turkey.
\end{abstract}

Keywords: social structure, social change, Turkish Modernization, Historical Materialism, Patrimonialism, Corporatism 


\section{Introduction}

The concept of social structure is used to express the entire corporate functioning within a certain human organization. All cultural features interacting with history, geography, population, and economic variables create the general framework of the social structure. There are two predominant concepts in explaining the social structure of today's Turkey. These mutually complementary concepts are patrimonialism and corporatism, which have been transferred from the Ottoman social structure to the present. These concepts include the general world views, social and human perceptions in the fields of politics, family, and bureaucracy. More precisely, in the social structure of today's Turkey, the general human relations are shaped by the mold of the patrimonial and corporatist culture elements. Patrimonial and corporatist culture elements form the unique characteristics of Turkey's social structure. On the other hand, they can also be regarded as the products of some economic and social conditions that differ from or resemble the Western social structure. The land tenure system, production relations, and political conditions unique to the Ottoman social structure were effective in the development of these two basic cultural elements and their transfer to today

The cultural elements learned and passed down from generation to generation tend to resist the change and continue their existence. In addition, as noted by the cultural anthropologists such as Maurice Godller or Emmanuel Terray, the characteristics of the social structure arising from its mode of production and relationships have a decisive effect on the survival of cultural elements which can be regarded as a reflection of these relations (Bağla and Galip, 1979: 50). The economic structures also constitute the general determinant variables in the political and cultural shaping of the social structure. Therefore, the studies on the social structure of Turkey should examine all the cultural elements within the economic, class-social reality from which they stemmed. The purpose of this study is to examine the concepts of patrimonialism and corporatism, which constitute the general characteristics of Turkey's social structure, along with their economic and social foundations. First, the concept of patrimonialism and then the corporatism will be discussed.

\section{Patrimonialist Culture and Its Material Foundations in the Social Structure of Turkey}

The arguments depicting the despotic governance relations of the eastern social structures can be found primarily in the works of the 18th-century enlightenment thinkers such as Montesquieu, Condorcet, Machiavelli, Helvetius, and Locke (Doğan, 2011: 166-167). Then Max Weber first used the term "patrimonialism" in defining the eastern societies and referred it as a concept explaining the overall hierarchical relations organized from top to bottom under the arbitrary authority of the ruler (Weber, 2003: 325-327; Marshall, 1999: 582). The infrastructural foundations of despotic governments in Asia and Africa were first mentioned in the correspondence between Marx and Engels. According to them, the strict central property relations that emerged necessarily due to the geographical conditions of eastern societies laid the material foundation of the eastern despotism. The need for organizing the irrigation works under the geographical conditions, where the soil was scarce and dry, necessitated the state ownership (Divitçioğlu, 1981: 17-19). So the dominant power of the state over the society in eastern societies stemmed primarily from the fact that the central property 
was in the hands of the state. According to Timur (1979:18-21), the tradition of strict central property in the Ottoman social structure was very strong with its roots dating back to the Gokturks and then the Seljuks.

On the other hand, the historical and economic conditions of the western societies are very different. Unlike the eastern societies, there had been no central political authority in Europe until the 17th century. The concept of "feudalism" we use for describing the history of western civilization is a concept referring to the division of political authorities. The general picture of European feudalism between the 5th and 15th centuries was in the form of autonomous scattered political units between which there were agreements or wars. The determinant reason for having scattered political organizations was the fact that the property was divided. As noted by the historians like Faulkner (2016: 117), Harman (2017: 144) or Huberman (2019:18), the geographical features of the European continent left no room for the central property relations. Thus, a multipolar political authority distribution determined the historical development in the western civilization. The fact that the cultural characteristics such as the "political participation", "civil society", and "individualization" are more highly institutionalized in the western civilization than the eastern societies can be considered as a strong result of the historical, material, and social conditions in question.

The social structure studies carried out in Turkey to compare the levels of political participation and civil society with those in the western society yielded the results that confirm our assertion. Çarkoğlu and Kalaycioğlu (2015)'s study comparing the results of 1509 interviews carried out across Turkey with those in the European countries can be cited as an example proving the issue. According to the findings of the study, the protest-oriented tendencies such as "collective petitioning" or "attending the events such as meetings and demonstrations" were found to be at a lower level than USA, Britain, Netherlands, France, Switzerland, and many European countries. These findings are in line with the following assertion made by Aköz (2018:163) in his study: In the eastern societies, the word "politics" is used in the sense of punishment and carries a negative connotation in the eyes of the society. To summarize, in general, the strict central economic structure and despotic political tradition of the eastern societies are of decisive importance in terms of the weakness of the tradition of criticism towards the concept of state within the large segment of society.

\section{Corporatist Culture and Its Material Foundations in the Social Structure of Turkey}

The second source of the perception that the state cannot be criticized is the corporatism. Corporatism, lexically meaning "solidarism", was used by Emile Durkheim as a theory referring to securing the bourgeoisie's social interests against the working class in Europe at the end of the 19th century. Opposing the "revolution" approach of Karl Marx, the theorist of the working class in the society; Durkheim emphasized that there was "compromise" and "harmony", rather than "conflict", between the parts of the social structure. The class disagreements should be resolved by means of compromise rather than the take-over of the political power by the working class. In this period, the organism theorists such as Spencer, who interpreted the reality of society in terms of the social interests of the bourgeoisie, developed similar findings. They saw the inequalities in society as natural and "complementary" differences, just like the inequalities between the limbs of a living organism. The concept of corporatism emerged in Europe; however, its effects of "making static" and "protecting the order" have been more powerful in the social structure of Turkey due to its historical and social past. While the conflict theories such as Feminism and Marxism immediately stood against Durkheim's functionalism in 
Europe where the authority was divided and there was a history full of class conflicts; the corporatist theory became an unchanging body defining the basic framework of society and politics in Turkey.

In Turkey, some common history books bring to the fore the fact that the Turkish revolution, which took place in the 20th century, is against the elites of the old sultanate. However, another theory that the Turkish modernization is completely against is Marxism. Kemalists, who dismissed the ulema and the other aristocracy from the administration with the republican revolution, took some very decisive measures against the possibility that the lower classes consisted of small production, peasantry, and labor came to the power. For example, when the Republic was proclaimed, Ziya Gökalp, the social theorist of the Turkish revolution, emphasized that there were no conflicts of interest and that a social peace prevailed among the professional groups which are the functionally interdependent and complementary organs of the social organism (Parla, 2015: 124). Indeed, in this period, the regulations such as Takrir-i Sükun Law (Law on establishment of order) dated 1925, the Code of Obligations dated 1926, the 1929 Penal Code or the Labor Law dated 1929 stipulated the peaceful settlement of disputes between workers and employers, and strictly forbade the workers from going on strikes and getting politically organized (Karpat, 2017: 160). The corporatist organization theory, which regulates the relations between the state and all social classes in a "harmonious" and "compromising" way, can be considered as the continuation of Durkheim's functionalist approach in the social structure of Turkey.

The corporatist theory of society and politics has been more strongly ingrained in Turkey's social structure compared to Europe. According to the findings of Parla (2005:8), all formations, from the Kemalist left and social democratic political parties to the far right political organizations, are under the corporatist umbrella in terms of basic intellectual categories. Thus, it is aimed to resolve the sharp contradictions between the classes within the social structure through pursuing "compromise" under the arbitration of the state and a class-based changeover of power is opposed by acting as a single voice. Unlike the western society, the corporatism has gained a strong position in Turkey's social structure. The main reason for this is the social philosophy based on unchangeableness which has been going on since the Ottoman social structure. As earlier emphasized by Berkes (1997:12), in the Ottoman society, while the term "order" was more important than the concept of state; the words "revolution" or "insurrection" were the most feared terms. The concept of "balance" (status quo) remained as a determinant factor at the foundation of the social order (Makal, 1997: 288). The most prominent reflection of the patrimonialist despotic state tradition in today's cultural structure is the strong corporatist perceptions towards "protecting the order".

\section{Conclusion}

As two basic world views being nurtured by the class and economic structure of Turkey, the patrimonialism and corporatism stand out as the cultural variables that should be used in explaining the social structure. Naturally, every change that emerges beyond our habits first causes astonishment and then suspicion. Because changes can be perceived as a threat to the continuation of the habitual life order. When considered from this point of view, in Turkey, the patrimonialism and corporatism are the cultural variables that can serve as a positive function in maintaining the political and economic order or "maintaining peace" in the social structure. On the other hand, these variables serve as a reactionary function against the new approaches such as "gender equality", "individualization", "the development of civil society", and "radical change of the social order for the benefit of the workers". This negative function is more valid for 
the social segments suffering the most from the social and economic order in effect today. On the other hand, the patrimonialist and corporatist culture serves as a very positive function for the social segments receiving the most share from today's social economic order.

There is a topic that needs to be discussed. Some of the Turkish social scientists working on the modernization history and political life in Turkey asserted that the evaluations of the western philosophers and sociologists on Turkey were "orientalist" and they refused these evaluations. According to them, the western civilization puts forward the argument of "superiority of the West" in order to defend its colonial goals on the East. The "eastern despotism" approach is also among these arguments that legitimize the western colonialism and, in fact, are "unsubstantial". This is how the "native sociology" movement, which finds an expression especially in Baykan Sezer, approaches the subject. However, the statecentered despotic tradition of the eastern societies is a fact accepted today by the majority of the native researchers working on history and society. Even just analyzing the history books on the Ottoman land and property order can give an idea about the phenomenon of eastern despotism. It is not a scientific attitude to attribute all theories to "the West's arguments of superiority" or to "their jealous gaze towards the East", to be sceptical about or refuse them just because they are originated from the European continent. Those who find the explanation based on the Asian Type of Production as "orientalist" or "western-centric" attribute the static state of the Ottoman social structure to the discovery of new trade routes in the 15th century. However, they have difficulty in explaining the "internal reasons".

The failure to objectively set forth the internal reasons means strengthening and protecting the state-centered understanding of people and society in the social structure of Turkey. Rejecting the "despotic state tradition" approach due to finding it orientalist and at the same time opposing the western imperialism is a contradictory attitude for a social scientist. However, the development of legal guarantees in the fields of human rights and freedoms against the central authority along with the civil society tradition is the determinant condition for the eastern civilization to stand against the western imperialism. The phenomena such as the social change, rationality, sound culture of debate, and perceiving the world and society from different perspectives can only survive in the societies where the democratic consciousness develops. In the history of civilization, there has been no social tradition that both has the hierarchical patrimonial features and demands justice and equality in the world. When considered from these perspectives, it is imperative that the theories on the current social structure of Turkey be examined objectively and in a scientific attitude, independent from the classifications such as "orientalist" or "western-centric".

\section{Kaynaklar}

Aköz, Seçkin. "Politika Kavramının Siyaset Kavramı Yerine Kullanılması ve Bilimsellik Tartışmaları Bağlamında Devlet Olgusuyla İlişkisi”, Van Yüzüncü Y1l Üniversitesi İktisadi ve İdari Bilimler Dergisi, vol. 3, no. 5, 2018.

Bağla, Lusin, and Arslan Galip. "Marksist Antropolojide Bazı Tartışmalar”, Birikim Dergisi, no. 56-57, 1979.

Berkes, Niyazi. İkiyüz Yıldır Neden Bocalıyoruz? Cumhuriyet Yayınları, 1997.

Çarkoğlu, Ali, and Ersin Kalaycıŏlu. "Türkiye'de ve Dünya'da Vatandaşlık." Bilimakademisi, 2015, https://bilimakademisi.org/wp-content/uploads/2015/12/Türkiyede-ve-Dunyada-Vatandaslik-2014-1.pdf.

Accessed 9 Feb. 2020.

Divitçioğlu, Sencer. Asya Üretim Tarzı ve Osmanlı Toplumu, Sermet Matbaası, 1981.

Doğan, Necmettin. "Patrimonyalizm Kavramına Eleştirel Bir Yaklaşım”, Liberal Düşünce Dergisi, vol. 16, no. 64, 2011. Faulkner, Neil. Marksist Dünya Tarihi, Neandertallerden Neoliberallere. Translated by Tuncel Öncel, Yordam Yayınları, 2016.

Harman, Chris. Halkların Dünya Tarihi. Translated by Uygur Kocabaşoğlu, Yordam Yayınları, 2017.

Huberman, Leo. Feodal Toplumdan Yirminci Yüzyıla. Translated by Murat Belge, İletişim Yayınları, 2019. 
Karpat, Kemal. Türk Demokrasi Tarihi, Timaş Yayınları, 2017

Makal, Ahmet. Osmanlı İmparatorluğu'nda Çalışma İlişkileri: 1850-1920, İmge Yayınları, 1997.

Marshall, Gordon. Sosyoloji Sözlüğü. Translated by Osman Akınhay and Derya Kömürcü, Bilim ve Sanat Yayınları, 1999.

Parla, Taha. Ziya Gökalp, Kemalizm ve Türkiye'de Korporatizm, Deniz Yayınları, 2005.

Timur, Taner. Osmanlı Toplumsal Düzeni, Turhan Yayınları, 1979.

Weber, Max. Sosyoloji Yazıları. Translated by Taha Parla, İletişim Yayınları, 2003.

Ulakbilge

\title{
TÜRKIYYE TOPLUM YAPISININ TANIMLANMASINDA TEMEL KAVRAMLAR OLARAK PATRIMONYALIZM VE KORPORATIZM
}

\author{
Mehmet Devrim TOPSES
}

ÖZ

Patrimonyalizm ve korporatizm, Türkiye'nin toplum yapısının açıklanmasında belirleyici derecede önem taşıyan kültürel değiş̧kenlerdir. Bireyler arasında olduğu gibi, birey ve devlet arasındaki ilişkiler de söz konusu kültürel değişkenlerin kalıplarına göre şekillenmektedir. Ataerkil aile bağları, hiyerarşik beklentiler, sivil toplumun zayıflığı ve itaatçi kültürün baskın gücü, söz konusu kültürel değişkenlerin toplum yapısındaki etkisine örnek olarak gösterilebilir. Bununla birlikte Türkiye'de patrimonyalist ve korporatist kültür unsurları, tarih içindeki ekonomik ve sınıfsal değişkenlerden beslenmiştir. Göktürk devletinden başlayarak sermaye birikimine izin vermeyen merkezi otorite ve despotik devlet geleneği patrimonyal kültürü beslemiştir. Diğer taraftan "nizam" ya da düzenin korunmasına devlet kavramından bile daha çok önem veren Osmanlı devlet geleneği, Türkiye'de korporatist kültür kodlarının gelişmesinde etkili olmuştur. 20. yüzyılın başında ise siyasi iktidarı ele geçiren Kemalistler, "korporatist toplum" görüşünü iktidarı daha alt sınıflar karşısında güvence altına alma işlevi yönünde desteklemişlerdir. Sonuç olarak Türkiye'nin günümüzdeki toplum yapısının açıklanmasında patrimonyalizm ve korporatizm kavramlarının kullanılması açık bir gerekliliktir.

Anahtar Kelimeler: toplumsal yapı, toplumsal değişme, Türk modernleşmesi, tarihsel materyalizm, Patrimonyalizm, Korporatizm 